\title{
Periapical Disease and the Prefrontal Cortex. Is there a Relationship between Calcium-Binding Protein and Neurodegenerative Diseases?
} Doença Periapical e Córtex Pré-Frontal. Existe uma Relação entre a Proteína de Ligação ao Cálcio e as Doenças Neurodegenerativas? Enfermedad Periapical y la Corteza Prefrontal.¿ Existe una Relación entre la Proteína Fijadora de Calcio y las Enfermedades Neurodegenerativas? Gestter Willian Lattari TESSARIN University Center North Paulista (UNORP), São José do Rio Preto, SP, Brazil https://orcid.org/0000-0002-7355-9652 Rodrigo Martins dos SANTOS Multicenter Post-Graduate Program in Physiological Sciences, SBFis, Department of Basic Sciences, São Paulo State University (Unesp), School of Dentistry, Araçatuba, Brazil https://orcid.org/0000-0002-5122-275X

Renato Felipe PEREIRA Multicenter Post-Graduate Program in Physiological Sciences, SBFis, Department of Basic Sciences, São Paulo State University (Unesp), School of Dentistry, Araçatuba, Brazil https://orcid.org/0000-0002-4696-4070

Maria Sara de Lima Coutinho MATTERA Multicenter Post-Graduate Program in Physiological Sciences, SBFis, Department of Basic Sciences, São Paulo State University (Unesp), School of Dentistry, Araçatuba, Brazil https://orcid.org/0000-0003-2288-708X

Thaís Verônica Saori TSOSURA

Multicenter Post-Graduate Program in Physiological Sciences, SBFis, Department of Basic Sciences, São Paulo State University (Unesp), School of Dentistry, Araçatuba, Brazil https://orcid.org/0000-0003-1708-4071

\section{Abstract}

Apical periodontitis (AP) or periapical lesion (PL) is an inflammatory disease that causes pain, loss of bone and destruction of other tissues of teeth support. This condition could be caused by caries, dental trauma and/or periapical microleakage wich is regulated by the immune system or inflammatory response. Several analyses have shown that endodontic infection can cause systemic alterations like stroke, insulin resistance, cardiovascular diseases and to contribute to the appearance of neurodegenerative disorders. The prefrontal cortex (PfC), positioned in the most anterior region of the brain, is essentially involved behavioral abilities, intellectual roles, cognition, learning and other functions. Neurons with laminar distribution in the PfC, especially in the lower layers express several types of calcium-binding proteins (CaBPs) like parvalbumin, calbindin and calretinin that are involved in calcium buffering into the brain (CNS). These proteins are co-localized with GABAergic neurons, main inhibitory cells into the brain. Piece of evidence has pointed out a relationship between apical periodontitis and neurodegenerative diseases where microorganisms and/or toxins produced in the teeth infection can penetrate the bloodstream, infiltrate the blood-brain barrier limit and active astrocytes and microglial cells in the central nervous system (CNS) and increase the releasing of pro-inflammatory cytokines promoting pyramidal and non-pyramidal neuronal degeneration. Thus, is there a relationship among apical periodontitis, oral hygiene and prefrontal cortex and neurodegenerative disorders?

Descriptors: Calcium-Binding Proteins; Inflammation; Neurodegenerative Diseases; Periodontal Diseases; Pre-Frontal Cortex.

\section{Resumo}

A periodontite apical (AP) ou lesão periapical (LP) é uma doença inflamatória que causa dor, perda óssea e destruição dos tecidos de suporte dos dentes. Esta condição pode ser causada por cárie, traumatismo dentário e/ou microinfiltração periapical, sendo regulada pelo sistema imunológico ou resposta inflamatória. Diversas análises mostraram que a infecção endodôntica pode causar alterações sistêmicas como acidente vascular cerebral, resistência à insulina, doenças cardiovasculares e contribuir para o aparecimento de doenças neurodegenerativas. $\mathrm{O}$ córtex pré-frontal $(\mathrm{PfC})$, posicionado na região mais anterior do cérebro, envolve essencialmente habilidades comportamentais, papéis intelectuais, cognição, aprendizagem e outras funções. Neurônios com distribuição laminar no PfC, especialmente nas camadas inferiores, expressam vários tipos de proteínas ligadoras de cálcio (CaBPs) como parvalbumina, calbindina e calretinina que estão envolvidas no tamponamento de cálcio no cérebro (SNC). Essas proteínas são co-localizadas com neurônios GABAérgicos, principais células inibitórias no cérebro. Evidências apontam para uma relação entre periodontite apical e doenças neurodegenerativas, onde microrganismos e/ou toxinas produzidas na infecção dos dentes podem penetrar na corrente sanguínea, infiltrar-se no limite da barreira hematoencefálica e ativar astrócitos e células microgliais no sistema nervoso central (SNC), aumentando a liberação de citocinas pró-inflamatórias, promovendo degeneração neuronal piramidal e não piramidal. Assim, existe relação entre periodontite apical, higiene bucal, córtex pré-frontal e distúrbios neurodegenerativos?

Descritores: Proteínas de Ligação ao Cálcio; Inflamação; Doenças Neurodegenerativas; Doenças Periodontais; Córtex Pré-Frontal.

\section{Resumen}

La periodontitis apical (PA) o lesión periapical $(P L)$ es una enfermedad inflamatoria que cursa con dolor, pérdida de hueso y destrucción de otros tejidos de soporte de los dientes. Esta condición puede ser causada por caries, trauma dental y/o microfiltración periapical, la cual es regulada por el sistema inmunológico o respuesta inflamatoria. Diversos análisis han demostrado que la infección endodóntica puede causar alteraciones sistémicas como accidente cerebrovascular, resistencia a la insulina, enfermedades cardiovasculares y contribuir a la aparición de trastornos neurodegenerativos. La corteza prefrontal (PfC), ubicada en la región más anterior del cerebro, está involucrada esencialmente en habilidades conductuales, roles intelectuales, cognición, aprendizaje y otras funciones. Las neuronas con distribución laminar en el PfC, especialmente en las capas inferiores, expresan varios tipos de proteínas de unión a calcio (CaBP) como parvalbúmina, calbindina y calretinina que están involucradas en el almacenamiento de calcio en el cerebro (SNC). Estas proteínas están co-localizadas con las neuronas GABAérgicas, las principales células inhibidoras del cerebro. La evidencia ha señalado una relación entre la periodontitis apical y las enfermedades neurodegenerativas donde los microorganismos y/o toxinas producidas en la infección dental pueden penetrar en el torrente sanguíneo, infiltrarse en el límite de la barrera hematoencefálica y activar astrocitos y células microgliales en el sistema nervioso central (SNC). ) y aumentar la liberación de citocinas proinflamatorias que promueven la degeneración neuronal piramidal y no piramidal. Entonces, ¿existe una relación entre la periodontitis apical, la higiene bucal y la corteza prefrontal y los trastornos neurodegenerativos?

Descriptores: Proteínas de Unión al Cálcio; Inflamación; Enfermedades Neurodegenerativas; Enfermedades Periodontales; Corteza Prefrontal.

INTRODUCTION

Apical periodontal (AP) or periapical lesion $(\mathrm{PL})$ is an inflammatory disease that causes pain, bone loss and other tissues of dental support ${ }^{1}$. Initially, this inflammatory condition is caused by microbial infections 
(predominantly due to gram-negative anaerobic bacteria) within endodontic root induced by caries and/or dental trauma and/or periapical microleakage ${ }^{1}$. Firstly, this condition is regulated by the host immune and/or inflammatory response $^{2,3}$. The presence of periapical inflammation actives the immunologic system stimulating several immune factors, like antibodies, complement system, arachidonic acid metabolites and pro-inflammatory cytokines ${ }^{4}$. Recently, several studies observed that inflammation of oral cavity can be a relationship with systemic disorders ${ }^{1}$ as diabetes ${ }^{5}$ cardiovascular and renal diseases ${ }^{6-12}$, preeclampsia $^{12}$, cirrhosis $^{13}$ and also neurological disorders ${ }^{14-19}$.

The brain has several functions as learning, speaking, cognitive control, spatial and visual perception, memory, language and others. In special, the prefrontal cortex (PfC), positioned in the most anterior portion of the brain, can be basically divided into three main regions: orbital (orbitofrontal, OfC), medial (MPfC) and lateral ${ }^{20}$. This portion of the brain has structural and functional heterogeneous regions with several distinct neurochemical areas that possibility various behavioral and cognitive features, attention, association, workmemory, sequencing of tasks, expression of emotional state and learning ${ }^{21-25}$. In addition, in vivo studies using neuroimaging techniques has been evidenced that different sections of the PfC are activated in different task demands or information processing ${ }^{26}$.

In the cerebral cortex, gammaaminobutyric acid (GABA) is the main inhibitor molecule of cortical excitatory neurons from the brain that has a role in modulation in the local neurotransmitter system, controlling the emotional and cognitive processes ${ }^{27}$. It's important to mention that approximately $30 \%$ of all synapses in the central nervous system (CNS) are interconnected by GABAergic interneurons and these types of cells which promote inhibitor synapsis into the brain also express calcium-binding protein (CaBPs), particularly parvalbumin (PV) and calbindin D$28 \mathrm{k}(\mathrm{CB})^{27-35}$. As described above, several studies have shown that AP may influence in systemic disorders promoting alterations in several tissues like skeletal muscle, cardiovascular blood vessels, bone, hepatic tissues, liver and others tissues s, $36-39^{\text {. }}$ Neurological disorders linked with inflammatory alterations caused by AP also has been shown and proven in several studies ${ }^{40-44}$. Thus, is there a relationship among periodontal disease, CaBPs and cerebral disorders as Alzheimer's and schizophrenia diseases?
- Neurotransmitter y-aminobutyric acid (GABA) and its receptors

The $y$-aminobutyric acid (GABA) is the main neurotransmitter in the mammalian brain that inhibit excitatory synapsis ${ }^{45}$. This discovery was reported in $1950^{46}$ and after various researches revealed that this neurotransmitter participates in most neurophysiological processes like memory, vigilance, muscle tension and anxiety ${ }^{47}$. It works through the inhibition, the interneurons that express GABA can actively act and to promote the brake on excitatory signaling into the cerebral cortex, including the PfC cortex, preventing the uncontrolled excitation from afferent structures and then cause the equilibrium or balance between inhibition and excitation stimulations ${ }^{48}$.

In another hand, this neurotransmitter has been linked with cerebral disorders, including alterations in behavioral aspects, pain, sleep, schizophrenia, epilepsy, Alzheimer's disease and autism spectrum disorders ${ }^{48,49}$. This relationship between GABA and several types of disorders could be interconnected because the decrease of GABA levels into the several regions of the brain, including the $\mathrm{PfC}$, promote the decrease of interactions between GABA and its receptors and the hyperpolarization of presynaptic neurons is abrogation by a decrease in chloride $\left(\mathrm{Cl}^{-}\right)$influx into the cell ${ }^{50}$, like observed by Auger and Floresco ${ }^{51}$ that analyzed by infusion of bicuculline, a $\mathrm{GABA}_{A} R$ antagonist, the disruption of memory and intellectual flexibility in multiple species. In the same way, in vivo analysis in autistics patients, the reduction of GABA and its receptors, like $\mathrm{GABA}_{A} R$, it was observed the reduction in gamma wave with great oscillations ${ }^{52}$.

In primates, the administration of bicuculline also revealed wich the circuit of pyramidal and non-pyramidal neurons in the PfC reduced the GABA signaling and severely limited the neurophysiologic ability of this circuit and promoted inability of working and relay correct motor commands with precision. Currently, clinical trials have been reported that the use of synthetic GABA drugs, for instance an agonist benzodiazepine, the lorazepam, modulate the glutamatergic signaling showing a potential treatment in psychosis and working memory in schizophrenic patients and situations of epilepsy in autistic patients ${ }^{48}$. It's important to mention that the PfC also has a laminar and columnar distribution of neurons. In the laminar distribution (layers I-VI), the cortical layer IV is rich in inhibitory GABAergic interneurons. These interneurons receive input from bioaminergic nuclei in the brain stem and "advance" to 
provide inhibition to local pyramidal excitatory neurons principally in cortical layers III and V. GABAergic interneurons have been implicated in the executive deficiencies of neurological diseases and may represent one of the main targets of atypical neuroleptics disease ${ }^{53}$. In this point of view, the neuronal circuits present in the PfC is widely controlled by interactions of GABAergic neurons which control several types of excitatory neurons located in all layers of the cerebral cortex being the interaction between GABAergic neurons - GABA receptors excitatory neurons the important equilibrium to the normal of many types of functions performed by the brain and then, the maintenance of this circuits along the life can contribute to a regression of emergence of various types of neuropsychiatric disorders.

\section{- Calcium-binding proteins (CBPs)}

Ions calcium $\left(\mathrm{Ca}^{2+}\right)$ are essential for the homeostasis in neurons contributing to their functions and survival. Furthermore, intracellular $\mathrm{Ca}^{2+}$ signaling in neurons and other types of cells is important to control gene transcription, membrane excitability, in release of several neurotransmitters and many other cellular procedures, including synaptic plasticity ${ }^{54-59}$. Calcium-binding proteins (CaBPs) are a large group of proteins consisting of over 240 subtypes $^{60}$, involved in several roles in the brain as regulation of the level of calcium ion, neuronal plasticity, brain development and functioning, neuroprotection, aging, memory, synapse formation and others functions ${ }^{30,61-66}$. Among the members of CaBPs, calbindin-D28k (CB), parvalbumin (PV) and calretinin (CR) are highly expressed in neurons of the CNS and the CBPs are colocalized in approximately 90\% neurons $y$-aminobutyric acid (GABA) positive ${ }^{30,64,67-69}$. CaBPs are expressed in pyramidal and non-pyramidal neurons distributed in several laminar and columnar regions into the brain, including the $\mathrm{PfC}$ in several primates human and non-human and rodents [67, 70-76]. Neurons that express PV, $\mathrm{CB}$ and $\mathrm{CR}$ which also express GABA are distributed in all layers of the PfC of human, rats and mice with major density in layer IV in a dysgranular and granular cortex ${ }^{67,71-75,77,78}$. In the same way, in capuchin monkey (Sapajus apella) this situation also is observed (unpublished data).

Recently, o lot of evidence suggests that AP presents a relationship with various types of neurological disease as stroke, amyotrophic lateral sclerosis, Alzheimer and Schizophrenia's diseases, depression and moods alterations $^{1,44,79-84}$ showing that systemic neuroinflammatory caused by AP can result in structural and functional disturbances into the brain, including alterations in neurotransmitters like GABA presents in pyramidal and nonpyramidal neurons and cell metabolism ${ }^{44,83}$, basically associating this condition with an increase of inflammatory cytokines into the cerebral parenchyma and stroma ${ }^{14,42,44,83,85,86}$. To support this data, an animal model of sepsis showed an increase of tumor necrosis factor alpha (TNF- $\alpha$ ), interleukin 1 beta (IL-1 $\beta$ ), interleukin 6 (IL-6), and interleukin 10 (IL-10) expressions in the $\mathrm{PfC}$ and hippocampus with PV positive interneuron loss linking this phenotype with cognitive impairments ${ }^{87}$ because the gamma oscillations have been associated with altered function of PV positive interneurons and neurological and/or psychiatric disorders with a manifestation of deficits in memory activity and executive functions ${ }^{33}$. This data has been confirmed in other studies of Alzheimer's disease, epilepsy, depression and autism (to review $^{88}$ ). Thus, of a neurophysiologic view, the CaBPs in neurons are essential to several types of functions and the imbalance of this family of proteins could promote the accumulation of calcium ions into the neurons and provide cell death $e$ then contribute to a decrease of inhibition of excitatory neurons.

- Apical periodonditis, neuroinflammation and neuronal loss

Several types of gram-positive, gramnegative, anaerobic and aerobic microorganisms are present in the oral cavity when the patient has good mouth hygiene. In this way, various tissues into the oral cavity are a perfect local to proliferate bacterial microorganisms and a biofilm form ${ }^{84}$. In several situations, such as the imbalance between the host and the infectious agents that constitutively inhabit the oral cavity, several carious lesions may occur, which, if left untreated, may cause the appearance of endodontic infections inhabited mainly by Prevotella intermedia, Streptococcus, Peptostreptococcus, Fusobacterium, Porphyromonas, Eubacteri and Parvimonas ${ }^{84}$. If the endodontic treatment is not successfully performed, the appearance of periapical abscesses can lead to the emergence of other types of microorganisms such as Fusobacterium nucleatum, Prevotella intermedia, Peptostreptococcus micros, Eubacteria, Peptostreptococcus anaeurobius ${ }^{84}$.

Pieces of evidence from several lines of investigation have pointed out to relationship between periodontics with neurological diseases, as precede described ${ }^{14,42,83,85,86,89,90}$. In special, the presence of periodontal disease 
causes inflammatory signaling where the toxins that are produced in this infection and/or the bacteria can be the bloodstream and reach the brain across the blood-brain barrier $(\mathrm{BBB})^{86}$. In the same way, periodontal disease increase circulating levels of pro-inflammatory cytokines, for example, TNF- $\alpha$, IL-1 $\beta$, IL-6, interleukin-8 (IL-8) and IL-10 induced by LPS (lipopolysaccharides) from periodontal microorganisms observed into the oral cavity and/or infiltrating to the bloodstream ${ }^{91-93}$. Between several virulence factors from grannegatives bacteria is the lipopolysaccharide (LPS) constitutively presents in cellular wall leave in vesicles and/or after its disintegration ${ }^{94}$.

The LPS is mainly recognized by Toll-like 4 receptor (TLR4), a receptor localized in the plasmalemma of immune cells and this interaction induces the activation of innate and realizes the induction of inflammatory responses ${ }^{95}$. The TLR4 in express in different types of cells (monocytes, macrophages and others) and tissues ${ }^{96}$, performing an important function on the development of chronic alterations linked with obesity and insulin resistance ${ }^{97,98}$. The TLR4 recognizes the LPS and promotes the synthesis of pro-inflammatory cytokines as TNF- $\alpha$, IL-1 $\beta$, IL-6, IL-8 and interleukin-12 (IL-12) which in turn act as endogenous inflammatory mediators through interaction with receptors found in different target cells. This situation between periodontitis and systemic inflammation was observed in analysis using patients with periodontitis where the levels of pro-inflammatory C-reactive protein (CRP) and leptin in serum were increased ${ }^{99}$. Besides that, in various organs and tissues was observed inflammation with an expression of pro-inflammatory mediators and reduced insulin resistance in adipose tissue as well as increased micro-RNA and TNF- $\alpha$ level in an animal model with administrations of Porphyromonas gingivalis $^{100}$.

Specifically, there are increasing studies supporting the relationship between oral infections and cerebral disorders ${ }^{14,101,102}$. Kamer et al. ${ }^{103}$ proposed that the inflammatory molecules from periodontitis into the CNS could promote the development of Alzheimer's disease. This inflammatory situation from the oral cavity may be to promote inflammation stress into the brain and cause microglial activation, astrogliosis, loss of neuronal synapses and neuronal degeneration promoting also a diminution of essential neurotransmitters like the GABA ${ }^{85,104}$. It is important to mention that the mechanism by which pro-inflammatory molecules from periodontitis arrive and increase in the brain molecular inflammatory involves two pathways: the blood/lymphatic circulation and/or the neural pathways ${ }^{104}$. Ilievski et al. ${ }^{14}$ observed neuroinflammation, neurodegeneration, microgliosis and astrogliosis after oral administration of Porphyromonas gingivalis in C57BL/6 mice. Zhang et al., [16] also reported the activation of astrocytes and microglia cells in the cerebral cortex and hippocampus after intraperitoneal injection of Porphyromonas gingivalis in C57BL/6 mice inducing cognate disorders. In the same way, using an animal model (ApoE ${ }^{\text {null }}$ mice) of experimental periodontitis infected with Fusobacterium nucleatum, $P$. gingivalis, $T$. denticola and $T$. forsythia revealed the existence of DNA from $P$. gingivalis showing that this bacteria can cross the $\mathrm{BBB}$, to activated the inflammatory pathways and pyramidal neurons of the hippocampus were opsonized with and they were likely to have been vulnerable from activated complement system ${ }^{105}$. Thus, the presence of periodontal pathogens endotoxins and/or periodontal pathogens possibly can activate the inflammatory cascade and initiate the neuroinflammation ${ }^{44,90}$ and could be associated with cognitive disorders ${ }^{16,17,105}$.

Calcium-binding proteins (CBPs) is a group of proteins that are involved in several functions like the regulation of the level of calcium ion, neuronal plasticity, brain development and functioning, neuroprotection, aging, memory and others functions ${ }^{30,65,66,106,107}$. On the other hand, the CBPs also are involved in cerebral pathological situations such as Alzheimer's and Parkinson's diseases, schizophrenia and bipolar disorder ${ }^{69,108,113}$. In the cerebral cortex, the main inhibitory neurotransmitter is gamma-aminobutyric acid (GABA) and approximately $25 \%$ of all neurons of the neocortex of the monkey's brain are GABAergic neurons and they also express CaBPs, particularly $\mathrm{PV}$ and $\mathrm{CB}^{21,28-35,114}$. Recently, there is an increase in the number of evidence and hypothesis showing that disruption of inhibitory neurons in PfC could be involved in several features of neuropsychiatric and neurodegenerative disorders like schizophrenia and Alzheimer Diseases ${ }^{33,115-117}$. Schizophrenia, a psychotic alteration that affect approximately 21 million people around the world ${ }^{118}$. Schizophrenic patients present mainly changes related to altered energy metabolism, demotivation and control of cognitive modulation, such as memory loss and inattention $^{119}$. The Alzheimer's disease is a common situation of dementia and this condition can be caused by several situations as amyloid 
plaque formation, accumulation of tau protein with oxidative and inflammatory brain damage in areas with advanced cognitive functions ${ }^{120-123}$ that promote the progressive loss of the functions of the brain ${ }^{124}$. In this way, the activation of the complement system (complement cascade), increase level of cytokine and chemokine expression can contribute to the development of this neurodegenerative disease ${ }^{17}$.

In special point, the CB mRNA levels in schizophrenia increased in post-mortem brain samples $^{125,126}$ as well as the number of $C B$ positive neurons was increased in the frontal cortex of people with schizophrenia ${ }^{112}$ and in prelimbic areas of the PfC from animal models for schizophrenia ${ }^{115}$, suggesting the compensatory mechanism to calcium buffer ${ }^{126}$. On the other hand, studies have shown the decrease of $\mathrm{CB}$ positive neurons in the $\mathrm{PfC}$ of patients with schizophrenia ${ }^{69,108,111,127,128}$. In the others conditions, neuronal diseases as Alzheimer's disease, dementia and dementia studies also have been reported the decreased of $C B$ cortical neurons ${ }^{108,129-132}$. These findings relatively cannot explain the functional activity of the CaBPs, in special $\mathrm{CB}$, in neuronal diseases with loss of GABAergic neurons, but the data of this study could help to understand, once this protein are differently distributed into areas of the PfC that are involved in cerebral diseases that present disturbance of the calcium.

Several scientific evidences have shown that PV also involved in neurodegenerative disorders. Volk et al. ${ }^{133}$ using quantitative PCR and in situ hybridization in postmortem samples of PfC from schizophrenia subjects observed lower PV positive neurons. In the same way, Beasley and Reynolds ${ }^{108}$ and Reynolds and Beasley ${ }^{134}$ showed by immunohistochemical technique significant reduction of PV positive neurons in the PfC. Moreover, one study using a sample from human PfC showed that basket cells axonal that express PV protein are reduced $^{135}$ and lower Pv mRNA expression ${ }^{125}$. Thus, the decrease in PV positive neurons with loss of gamma waves in schizophrenic patients has been associated with deficits in memory and cognitive functions ${ }^{136,137}$. The relationship among the altered function of PV neurons also confirmed in other neurological disorders like Alzheimer's disease, epilepsy, autism, and depression $^{88}$.

In this way, the possible link between AP and development of Alzheimer's and Parkinson's diseases may be related with two points: 1) systemic inflammation can increase in the CNS the levels of pro-inflammatory cytokines development the neuroinflammation that cause astroglial and microglial activation induced by AP; 2) neuroinflammation performed by invasion of periodontal pathogen and/or their inflammatory components (for instance: endotoxin, LPS, virulence factors and others) into the brain that also can the cause similar situation of neuroinflammation. In this way and as described above, the presence of the neuroinflammation into the brain caused by bacterial and/or toxins from the AP can activate the astrocytes and the abnormal calcium and glutamate homeostasis in reactive astrocytes can contribute to the pathogenesis of Alzheimer's disease ${ }^{138}$. For instance, studies using brains of animal models to Alzheimer's diseases, the calcium-mediated signaling from astrocytes and gliotransmitter releases can be associated with disruption of $\beta$-amyloid peptide $(A \beta)$, which indicates astrocyte dysfunction and contribute to the earliest neuronal deficits and loss in Alzheimer's disease ${ }^{139}$. Besides that, in mice model, excessive release of GABA by reactive astrocytes resulted in tonic inhibition of dentate gyrus granule cells in the hippocampus of Alzheimer mice model. Remarkably, inhibition of GABA or the use of pharmacological blockade of GABA transporters possibility the restore of synaptic and memory deficits ${ }^{140}$. Moreover, in an animal model using a long-term ligature around the tooth, Li et al. ${ }^{141}$ observed alveolar bone loss and inflammatory alterations in dental support tissues with progressive cognitive deficits during a 12-month period as well as neuronal, synaptic disruption and glial activation. To support these data, using human or animal model analysis also were observed the presence of bacteria and/or toxins into the brain via peripheral nerves route ${ }^{142,143}$. Therefore, reactive astrocytes increase the expression of GFAP and $S 100 \beta$ proteins, pro-inflammatory cytokines and other neuromodulators that can promote the cascade event and contribute with the Alzheimer disease ${ }^{144}$.

The health situation of the dental element and/or oral promotesa normal condition of dental support tissues and other oral tissues without range to the bloodstream of bacteria and/or toxins that cause a host immune/inflammatory response. Another hand, the presence of caries and/or other situations that cause endodontic infection can promote the liberation in the bloodstream of several microorganisms and/or theirs products that cross the blood-brain barrier and induce an astrocytic reaction and activation of microglial cells. This situation increases the liberation from astrocytes and microglial cells of cytokines pro-inflammatory into the prefrontal 
cortex contributing to a neuronal loss of several types, including the gabaergic pyramidal and non-pyramidal that express calcium-binding proteins constitutively, contributing with the appearance of neurodegenerative disorders like Alzheimer's and Parkinson's diseases and schizophrenia. Any portion of the prefrontal cortex with neurons expresses constitutively calbindin, calretini and parvalbumin.

Similarly, it is possible that bacteria and/or toxins arrive in the cerebral cortex by bloodstream via, induce a brain inflammation with disorganization in dopaminergic neurotransmission in the basal nuclei and neuronal degeneration in the substantia nigra observed in situations of Parkinson's disease with activation of astrocytes and microglia ${ }^{144-150}$, probably disclosing the similar condition described above where the systemic inflammation can increase in the CNS the levels of various pro-inflammatory cytokines that to disclose a neuroinflammation situation promoting astroglial and microglial activation induced by AP and the neuroinflammation performed by direct invasion of periodontal pathogen and/or their inflammatory components into the PfC can cause pyramidal and nonpyramidal neuronal loss, specifically that have presents constitutive CaBPs, essential molecules involved in several important functions of this type of cells. Thus, the neuroinflammation could contribute to several types of neurological disorders where is observed neuronal loss ${ }^{117}$.

FINAL CONSIDERATION

The CNS are considered the place with the right protection in the body. However, several studies have been shown the relationship with oral diseases and systemic disorders including neurological disorders.

Periodontitis is very common in a great portion of the global population and the bacterias and/or toxins from this disease can cause a series of immune responses that disclosing an inflammatory cascade in the body. In the brain, this situation is not different from the others tissues and then the neuroinflammation can promote the neuronal loss and activation of astrocytes and neuroglia and the mainly calcium-binding protein (CaBPs) may be involved in neurodegenerative disorders like Alzheimer, schizophrenia and others neurodegenerative diseases. These relationships can be interconnected by fluctuations in levels of calcium ions that caused alterations in cerebral homeostasis and neurodegeneration in neurons and/or interneurons GABAergic positive to parvalbumin $(P V)$, calretinin (CR) and calbindin D-28k (CB) that are involved in several functions into the brain mainly in inhibitory synapsis showing a possible interrelation among periodontal/periapical infections and neurodegenerative diseases. Thus, periodontitis treatment using conventional treatment may be a benefit to prevent several types of brain diseases, improve the Alzheimer's and Parkinson's conditions or extend the onset of the disease, improving the quality and expectancy of life in the global population.

REFERENCES

1. Cintra LTA, Estrela C, Azuma MM, Queiroz IOA, Kawai T, Gomes-Filho JE. Endodontic medicine: interrelationships among apical periodontitis, systemic disorders, and tissue responses of dental materials. Braz Oral Res 2018;32(suppl 1):e68.

2. Gazivoda D, Dzopalic T, Bozic B, Tatomirovic Z, Brkic Z, Colic M. Production of proinflammatory and immunoregulatory cytokines by inflammatory cells from periapical lesions in culture. Journal of oral pathology \& medicine : official publication of the International Association of Oral Pathologists and the American Academy of Oral Pathology 2009;38(7).

3. Sasaki $H$, Hirai $K$, Martins CM, Furusho $H$, Battaglino $\mathrm{R}$, Hashimoto K. Interrelationship between Periapical Lesion and Systemic Metabolic Disorders. Curr Pharm Des 2016;22(15):2204-15.

4. Stashenko P, Teles R, D'Souza R. Periapical inflammatory responses and their modulation. Critical reviews in oral biology and medicine : an official publication of the American Association of Oral Biologists 1998;9(4).

5. Schulze A, Schönauer M, Busse M. Sudden improvement of insulin sensitivity related to an endodontic treatment. Journal of periodontology 2007;78(12).

6. Caplan DJ, Chasen JB, Krall EA, Cai J, Kang S, Garcia RI, et al. Lesions of endodontic origin and risk of coronary heart disease. J Dent Res 2006;85(11):996-1000.

7. Pasqualini D, Bergandi $L$, Palumbo $L$, Borraccino A, Dambra V, Alovisi $M$, et al. Association among oral health, apical periodontitis, CD14 polymorphisms, and coronary heart disease in middle-aged adults. $\mathrm{J}$ Endod 2012;38(12):1570-7.

8. Costa $\mathrm{TH}$, de Figueiredo Neto JA, de Oliveira AE, Lopes e Maia Mde F, de Almeida AL. Association between chronic apical periodontitis and coronary artery disease. $\mathrm{J}$ Endod 2014;40(2):164-7. 
9. Martins CM, Sasaki H, Hirai K, Andrada AC, Gomes-Filho JE. Relationship between hypertension and periapical lesion: an in vitro and in vivo study. Braz Oral Res 2016;30(1):e78.

10. Rashmi N, Galhotra V, Goel P, Rajguru JP, Jha SK, Kulkarni K. Assessment of C-reactive Proteins, Cytokines, and Plasma Protein Levels in Hypertensive Patients with Apical Periodontitis. J Contemp Dent Pract 2017;18(6):516-21.

11. Singhal RK, Rai B. sTNF-R Levels: Apical Periodontitis Linked to Coronary Heart Disease. Open Access Maced J Med Sci 2017;5(1):6871.

12. Khalighinejad N, Aminoshariae A, Kulild JC, Sahly K, Mickel A. Association of End-stage Renal Disease with Radiographically and Clinically Diagnosed Apical Periodontitis: A Hospital-based Study. J Endod 2017;43(9):1438-41.

13. Gronkjaer LL, Holmstrup P, Schou S, Schwartz $\mathrm{K}$, Kongstad J, Jepsen P, et al. Presence and consequence of tooth periapical radiolucency in patients with cirrhosis. Hepat Med 2016;8:97103.

14. llievski V, Zuchowska PK, Green SJ, Toth PT, Ragozzino ME, Le $\mathrm{K}$, et al. Chronic oral application of a periodontal pathogen results in brain inflammation, neurodegeneration and amyloid beta production in wild type mice. PLoS One 2018;13(10):e0204941.

15. Holmer J, Eriksdotter $M$, Schultzberg $M$, Pussinen PJ, Buhlin K. Association between periodontitis and risk of Alzheimer's disease, mild cognitive impairment and subjective cognitive decline: A case-control study. J Clin Periodontol 2018;45(11):1287-98.

16. Zhang J, Yu C, Zhang X, Chen H, Dong J, Lu $W$, et al. Porphyromonas gingivalis lipopolysaccharide induces cognitive dysfunction, mediated by neuronal inflammation via activation of the TLR4 signaling pathway in C57BL/6 mice. J Neuroinflammation 2018;15(1):37.

17. Bui FQ, Almeida-da-Silva CLC, Huynh B, Trinh A, Liu J, Woodward J, et al. Association between periodontal pathogens and systemic disease. Biomed J 2019;42(1):27-35.

18. Diaz-Zuniga J, Munoz Y, Melgar-Rodriguez S, More J, Bruna B, Lobos P, et al. Serotype b of Aggregatibacter actinomycetemcomitans triggers pro-inflammatory responses and amyloid beta secretion in hippocampal cells: a novel link between periodontitis and Alzheimer $s$ disease? J Oral Microbiol 2019;11(1):1586423.

19. Singhrao SK, Olsen I. Assessing the role of Porphyromonas gingivalis in periodontitis to determine a causative relationship with
Alzheimer's disease. $\mathrm{J}$ Oral Microbiol 2019;11(1):1563405.

20. Fuster JM. The prefrontal cortex--an update: time is of the essence. Neuron 2001;30(2).

21. Gabbott PL, Bacon SJ. Local circuit neurons in the medial prefrontal cortex (areas 24a,b,c, 25 and 32) in the monkey: I. Cell morphology and morphometrics. J Comp Neurol 1996; 364(4):567-608.

22. Boschin EA, Buckley MJ. Differential contributions of dorsolateral and frontopolar cortices to working memory processes in the primate. Front Syst Neurosci 2015;9:144.

23. Boschin EA, Piekema C, Buckley MJ. Essential functions of primate frontopolar cortex in cognition. Proc Natl Acad Sci U S A 2015;112(9):E1020-7.

24. Rushworth MF, Nixon PD, Eacott MJ, Passingham RE. Ventral prefrontal cortex is not essential for working memory. The Journal of neuroscience : the official journal of the Society for Neuroscience 1997;17(12).

25. Cruz-Rizzolo RJ, Horta-Júnior JdA, Bittencourt JC, Ervolino E, de Oliveira JA, Casatti CA. Distribution of NADPH-diaphorase-positive neurons in the prefrontal cortex of the Cebus monkey. Brain research 2006;1083(1).

26. Wilson CR, Gaffan D, Browning PG, Baxter MG. Functional localization within the prefrontal cortex: missing the forest for the trees? Trends Neurosci 2010;33(12):533-40.

27. Schmidt MJ, Mirnics K. Neurodevelopment, GABA system dysfunction, and schizophrenia. Neuropsychopharmacology 2015;40(1):190206.

28. Celio MR. Parvalbumin in most gammaaminobutyric acid-containing neurons of the rat cerebral cortex. Science 1986;231(4741):995-7.

29. Kosaka T, Heizmann CW, Tateishi K, Hamaoka Y, Hama K. An aspect of the organizational principle of the gamma-aminobutyric acidergic system in the cerebral cortex. Brain Res 1987;409(2):403-8.

30. Demeulemeester $H$, Vandesande F, Orban GA, Heizmann CW, Pochet R. Calbindin D-28K and parvalbumin immunoreactivity is confined to two separate neuronal subpopulations in the cat visual cortex, whereas partial coexistence is shown in the dorsal lateral geniculate nucleus. Neurosci Lett 1989;99(1-2):6-11.

31. Hendry SH, Jones EG, Emson PC, Lawson DE, Heizmann CW, Streit P. Two classes of cortical GABA neurons defined by differential calcium binding protein immunoreactivities. Exp Brain Res 1989;76(2):467-72.

32. DeFelipe J, Hendry SH, Hashikawa T, Molinari $M$, Jones EG. A microcolumnar structure of monkey cerebral cortex revealed by immunocytochemical studies of double bouquet cell axons. Neuroscience 1990;37(3):655-73. 
33. Rozycka A, Liguz-Lecznar M. The space where aging acts: focus on the GABAergic synapse. Aging Cell 2017;16(4):634-43.

34. DeFelipe J, Jones EG. High-Resolution Light and Electron Microscopic Immunocytochemistry of Colocalized GABA and Calbindin D-28k in Somata and Double Bouquet Cell Axons of Monkey Somatosensory Cortex. Eur J Neurosci 1992;4(1):46-60.

35. Hendry SH, Jones EG. GABA neuronal subpopulations in cat primary auditory cortex: co-localization with calcium binding proteins. Brain Res 1991;543(1):45-55.

36. Cintra LT, da Silva Facundo AC, Azuma MM, Sumida DH, Astolphi RD, Bomfim SR, et al. Pulpal and periodontal diseases increase triglyceride levels in diabetic rats. Clin Oral Investig 2013;17(6):1595-9.

37. Cintra LT, Samuel RO, Facundo AC, Prieto AK, Sumida DH, Bomfim SR, et al. Relationships between oral infections and blood glucose concentrations or $\mathrm{HbA} 1 \mathrm{c}$ levels in normal and diabetic rats. Int Endod J 2014;47(3):228-37.

38. Pereira RF, Cintra LTA, Tessarin GWL, Chiba FY, de Lima Coutinho Mattera MS, Scaramele NF, et al. Periapical Lesions Increase Macrophage Infiltration and Inflammatory Signaling in Muscle Tissue of Rats. J Endod 2017;43(6):982-8.

39. Astolphi RD, Curbete MM, Chiba FY, Cintra LT, Ervolino E, da Mota MS, et al. Periapical Lesions Decrease Insulin Signaling in Rat Skeletal Muscle. J Endod 2015;41(8):1305-10.

40. Zoellner $H$. Dental infection and vascular disease. Semin Thromb Hemost 2011;37(3):181-92.

41. Moazzam AA, Rajagopal SM, Sedghizadeh PP, Zada G, Habibian M. Intracranial bacterial infections of oral origin. J Clin Neurosci 2015;22(5):800-6.

42. Aarabi G, Thomalla G, Heydecke G, Seedorf U. Chronic oral infection: An emerging risk factor of cerebral small vessel disease. Oral Dis 2019;25(3):710-9.

43. Tatullo M, Codispoti B, Makeeva I, Benincasa C, Spagnuolo G. From Mouth to Brain: Neuroendocrine Markers Play as a Crosstalk Among Oral and Neurodegenerative Diseases. Front Endocrinol (Lausanne) 2019;10:378.

44. Wang J, Geng X, Sun J, Zhang S, Yu W, Zhang $X$, et al. The risk of periodontitis for peripheral vascular disease: a systematic review. Rev Cardiovasc Med 2019;20(2):81-9.

45. Petroff OAC. GABA and glutamate in the human brain. The Neuroscientist : a review journal bringing neurobiology, neurology and psychiatry 2002;8(6).

46. Spiering MJ. The discovery of GABA in the brain. J Biol Chem. 2018, p. 19159-60.

47. Zeller A, Jurd R, Lambert S, Arras M, Drexler B, Grashoff $C$, et al. Inhibitory ligand-gated ion channels as substrates for general anesthetic actions. Handbook of experimental pharmacology 2008(182).

48. Ferguson BR, Gao WJ. PV Interneurons: Critical Regulators of E/l Balance for Prefrontal Cortex-Dependent Behavior and Psychiatric Disorders. Frontiers in neural circuits 2018;12.

49. Strandwitz P. Neurotransmitter modulation by the gut microbiota. Brain Res 2018;1693(Pt B):128-33.

50. Calvo-Flores BG, Vinnakota C, Govindpani K, Waldvogel HJ, Faull RLM, Kwakowsky A. The GABAergic system as a therapeutic target for Alzheimer's disease. Journal of neurochemistry 2018;146(6).

51. Auger ML, Floresco SB. Prefrontal cortical GABA modulation of spatial reference and working memory. The international journal of neuropsychopharmacology 2014;18(2).

52. Sun J, Jayathilake K, Zhao Z, Meltzer HY. Investigating association of four gene regions (GABRB3, MAOB, PAH, and SLC6A4) with five symptoms in schizophrenia. Psychiatry research 2012;198(2).

53. Royall DR, Lauterbach EC, Cummings JL, Reeve A, Rummans TA, Kaufer DI, et al. Executive control function: a review of its promise and challenges for clinical research. A report from the Committee on Research of the American Neuropsychiatric Association. The Journal of neuropsychiatry and clinical neurosciences 2002;14(4).

54.Berridge MJ. Neuronal calcium signaling. Neuron 1998;21(1):13-26.

55. Wojda U, Salinska E, Kuznicki J. Calcium ions in neuronal degeneration. IUBMB Life 2008;60(9):575-90.

56. Brini M, Cali T, Ottolini D, Carafoli E. Neuronal calcium signaling: function and dysfunction. Cell Mol Life Sci 2014;71(15):2787-814.

57. Gattoni G, Bernocchi G. Calcium-Binding Proteins in the Nervous System during Hibernation: Neuroprotective Strategies in Hypometabolic Conditions? Int J Mol Sci 2019;20(9).

58.ljomone OM, Aluko OM, Okoh COA, Martins AC, Jr., Aschner M. Role for calcium signaling in manganese neurotoxicity. J Trace Elem Med Biol 2019;56:146-55.

59. Wypych D, Pomorski P. Calcium Signaling in Glioma Cells: The Role of Nucleotide Receptors. Adv Exp Med Biol 2020;1202:67-86.

60. Schwaller B. The continuing disappearance of "pure" Ca2+ buffers. Cell Mol Life Sci 2009;66(2):275-300.

61. Celio MR. Calbindin D-28k and parvalbumin in the rat nervous system. Neuroscience 1990;35(2):375-475.

62. Lukas W, Jones KA. Cortical neurons containing calretinin are selectively resistant to 
calcium overload and excitotoxicity in vitro. Neuroscience 1994;61(2):307-16.

63. Molinari M, Dell'Anna ME, Rausell E, Leggio MG, Hashikawa T, Jones EG. Auditory thalamocortical pathways defined in monkeys by calcium-binding protein immunoreactivity. $\mathrm{J}$ Comp Neurol 1995;362(2):171-94.

64. Hof PR, Glezer, II, Conde F, Flagg RA, Rubin MB, Nimchinsky EA, et al. Cellular distribution of the calcium-binding proteins parvalbumin, calbindin, and calretinin in the neocortex of mammals: phylogenetic and developmental patterns. J Chem Neuroanat 1999;16(2):77116.

65.Zaitsev AV, Gonzalez-Burgos G, Povysheva NV, Kroner S, Lewis DA, Krimer LS. Localization of calcium-binding proteins in physiologically and morphologically characterized interneurons of monkey dorsolateral prefrontal cortex. Cereb Cortex 2005;15(8):1178-86.

66.Zakowski W. Neurochemistry of the Anterior Thalamic Nuclei. Mol Neurobiol 2017;54(7):5248-63.

67. Freund TF, Gulyas AI. GABAergic interneurons containing calbindin D28K or somatostatin are major targets of GABAergic basal forebrain afferents in the rat neocortex. J Comp Neurol 1991;314(1):187-99.

68. Hof PR, Mufson EJ, Morrison JH. Human orbitofrontal cortex: cytoarchitecture and quantitative immunohistochemical parcellation. J Comp Neurol 1995;359(1):48-68.

69. Eyles DW, McGrath JJ, Reynolds GP. Neuronal calcium-binding proteins and schizophrenia. Schizophr Res 2002;57(1):27-34.

70. Blumcke I, Celio MR. Parvalbumin and calbindin D-28k immunoreactivities coexist within cytochrome oxidase-rich compartments of squirrel monkey area 18. Exp Brain Res 1992;92(1):39-45.

71. Goodchild AK, Martin PR. The distribution of calcium-binding proteins in the lateral geniculate nucleus and visual cortex of a New World monkey, the marmoset, Callithrix jacchus. Vis Neurosci 1998;15(4):625-42.

72. Gibson CL, Clowry GJ. The effect on motor cortical neuronal development of focal lesions to the sub-cortical white matter in the neonatal rat: a model for periventricular leukomalacia. Int J Dev Neurosci 2003;21(4):171-82.

73. Pinheiro Botelho E, Guimaraes Martins Soares J, da Silva Pereira S, Fiorani M, Gattass R. Distribution of calbindin-28kD and parvalbumin in V1 in normal adult Cebus apella monkeys and in monkeys with retinal lesions. Brain Res 2006;1117(1):1-11.

74. Henny $P$, Jones BE. Projections from basal forebrain to prefrontal cortex comprise cholinergic, GABAergic and glutamatergic inputs to pyramidal cells or interneurons. Eur $\mathrm{J}$ Neurosci 2008;27(3):654-70.

75. Ahn JH, Hong S, Park JH, Kim IH, Cho JH, Lee TK, et al. Immunoreactivities of calbindinD28k, calretinin and parvalbumin in the somatosensory cortex of rodents during normal aging. Mol Med Rep 2017;16(5):7191-8.

76. Campos LM, Osorio EC, Santos GL, Nogueira MI, Cruz-Rizzolo RJ, Pinato L. Temporal changes in calcium-binding proteins in the medial geniculate nucleus of the monkey Sapajus apella. J Chem Neuroanat 2015;68:4554.

77. Blumcke I, Hof PR, Morrison JH, Celio MR. Parvalbumin in the monkey striate cortex: a quantitative immunoelectron-microscopy study. Brain Res 1991;554(1-2):237-43.

78. Campos LM, Cruz-Rizzolo RJ, Pinato L. The primate seahorse rhythm. Brain Res 2015;1613:81-91.

79. Cueno ME, Ochiai K. Gingival Periodontal Disease (PD) Level-Butyric Acid Affects the Systemic Blood and Brain Organ: Insights Into the Systemic Inflammation of Periodontal Disease. Front Immunol 2018;9:1158.

80. Maldonado A, Laugisch O, Burgin W, Sculean A, Eick S. Clinical periodontal variables in patients with and without dementia-a systematic review and meta-analysis. Clin Oral Investig 2018;22(7):2463-74.

81. Campanella V, Oberti L, Gabrione F, GonzalezValero L, Hernandez-Martinez V, SilvestreRangil J. Periodontitis and cerebrovascular disease: a new novel in medicine. J Biol Regul Homeost Agents 2019;33(3 Suppl. 1):135-44.

82. Fagundes NCF, Almeida A, Vilhena KFB, Magno MB, Maia LC, Lima RR. Periodontitis As A Risk Factor For Stroke: A Systematic Review And Meta-Analysis. Vasc Health Risk Manag 2019;15:519-32.

83. Hashioka S, Inoue K, Miyaoka T, Hayashida M, Wake R, Oh-Nishi A, et al. The Possible Causal Link of Periodontitis to Neuropsychiatric Disorders: More Than Psychosocial Mechanisms. Int J Mol Sci 2019;20(15).

84. Dioguardi M, Crincoli V, Laino L, Alovisi M, Sovereto D, Mastrangelo F, et al. The Role of Periodontitis and Periodontal Bacteria in the Onset and Progression of Alzheimer's Disease: A Systematic Review. J Clin Med 2020;9(2).

85. Gurav AN. Alzheimer's disease and periodontitis--an elusive link. Rev Assoc Med Bras (1992) 2014;60(2):173-80.

86. Ganesh P, Karthikeyan R, Muthukumaraswamy A, Anand J. A Potential Role of Periodontal Inflammation in Alzheimer's Disease: A Review. Oral Health Prev Dent 2017;15(1):7-12.

87. Ji MH, Qiu LL, Tang H, Ju LS, Sun XR, Zhang $\mathrm{H}$, et al. Sepsis-induced selective parvalbumin interneuron phenotype loss and cognitive 
impairments may be mediated by NADPH oxidase 2 activation in mice. $J$ Neuroinflammation 2015;12:182.

88. Rossignol E. Genetics and function of neocortical GABAergic interneurons in neurodevelopmental disorders. Neural Plast 2011;2011:649325.

89. McKenzie JA, Spielman LJ, Pointer CB, Lowry JR, Bajwa E, Lee CW, et al. Neuroinflammation as a Common Mechanism Associated with the Modifiable Risk Factors for Alzheimer's and Parkinson's Diseases. Curr Aging Sci 2017;10(3):158-76.

90.Wang RP, Ho YS, Leung WK, Goto T, Chang RC. Systemic inflammation linking chronic periodontitis to cognitive decline. Brain Behav Immun 2019;81:63-73.

91. Trindade SC, Olczak T, Gomes-Filho IS, Moura-Costa LF, Cerqueira EM, Galdino-Neto $M$, et al. Induction of interleukin (IL)-1beta, IL$10, \quad I L-8$ and immunoglobulin $G$ by Porphyromonas gingivalis HmuY in humans. $J$ Periodontal Res 2012;47(1):27-32.

92. Carvalho-Filho PC, Gomes-Filho IS, Meyer R, Olczak T, Xavier MT, Trindade SC. Role of Porphyromonas gingivalis $\mathrm{HmuY}$ in Immunopathogenesis of Chronic Periodontitis. Mediators Inflamm 2016;2016.

93. O'Boyle C, Haley MJ, Lemarchand E, Smith CJ, Allan SM, Konkel JE, et al. Ligature-induced periodontitis induces systemic inflammation but does not alter acute outcome after stroke in mice. Int J Stroke. 2020, p. 175-87.

94. Gomes B, Herrera DR. Etiologic role of root canal infection in apical periodontitis and its relationship with clinical symptomatology. Braz Oral Res 2018;32(suppl 1):e69.

95. Li ZG, Li JJ, Sun CA, Jin Y, Wu WW. Interleukin-18 promoter polymorphisms and plasma levels are associated with increased risk of periodontitis: a meta-analysis. Inflamm Res 2014;63(1):45-52.

96. Vaure C, Liu Y. A comparative review of toll-like receptor 4 expression and functionality in different animal species. Front Immunol 2014;5:316.

97. Pal D, Dasgupta S, Kundu R, Maitra S, Das G, Mukhopadhyay $S$, et al. Fetuin-A acts as an endogenous ligand of TLR4 to promote lipidinduced insulin resistance. Nat Med 2012;18(8):1279-85.

98. Reynolds JM, Martinez GJ, Chung Y, Dong C. Toll-like receptor 4 signaling in $\mathrm{T}$ cells promotes autoimmune inflammation. Proc Natl Acad Sci U S A 2012;109(32):13064-9.

99. Ardila CM, Guzman IC. Comparison of serum amyloid $A$ protein and $C$-reactive protein levels as inflammatory markers in periodontitis. J Periodontal Implant Sci 2015;45(1):14-22.
100. Arimatsu $\mathrm{K}$, Yamada $\mathrm{H}$, Miyazawa $\mathrm{H}$, Minagawa T, Nakajima M, Ryder MI, et al. Oral pathobiont induces systemic inflammation and metabolic changes associated with alteration of gut microbiota. Sci Rep 2014;4:4828.

101. Poole S, Singhrao SK, Kesavalu L, Curtis $M A$, Crean S. Determining the presence of periodontopathic virulence factors in short-term postmortem Alzheimer's disease brain tissue. J Alzheimers Dis 2013;36(4):665-77.

102. Kamer AR, Fortea JO, Videla S, Mayoral A, Janal M, Carmona-Iragui $M$, et al. Periodontal disease's contribution to Alzheimer's disease progression in Down syndrome. Alzheimers Dement (Amst) 2016;2:49-57.

103. Kamer AR, Morse DE, Holm-Pedersen P, Mortensen EL, Avlund K. Periodontal inflammation in relation to cognitive function in an older adult Danish population. Journal of Alzheimer's disease : JAD 2012;28(3).

104. Ding Y, Ren J, Yu H, Yu W, Zhou Y. Porphyromonas gingivalis, a periodontitis causing bacterium, induces memory impairment and age-dependent neuroinflammation in mice. Immun Ageing 2018;15:6.

105. Poole S, Singhrao SK, Chukkapalli S, Rivera M, Velsko I, Kesavalu L, et al. Active invasion of Porphyromonas gingivalis and infection-induced complement activation in ApoE-/- mice brains. J Alzheimers Dis 2015;43(1):67-80.

106. D'Orlando C, Fellay B, Schwaller B, Salicio V, Bloc A, Gotzos V, et al. Calretinin and calbindin D-28k delay the onset of cell death after excitotoxic stimulation in transfected P19 cells. Brain Res 2001;909(1-2):145-58.

107. Yang $W$, Jones LM, Isley L, Ye Y, Lee HW, Wilkins $A$, et al. Rational design of a calciumbinding protein. $\mathrm{J}$ Am Chem Soc 2003;125(20):6165-71.

108. Beasley CL, Reynolds GP. Parvalbuminimmunoreactive neurons are reduced in the prefrontal cortex of schizophrenics. Schizophr Res 1997;24(3):349-55.

109. Yew DT, Luo CB, Heizmann CW, Chan WY. Differential expression of calretinin, calbindin D28K and parvalbumin in the developing human cerebellum. Brain Res Dev Brain Res 1997;103(1):37-45.

110. Danos P, Baumann B, Bernstein HG, Franz $M$, Stauch $R$, Northoff $G$, et al. Schizophrenia and anteroventral thalamic nucleus: selective decrease of parvalbuminimmunoreactive thalamocortical projection neurons. Psychiatry Res 1998;82(1):1-10.

111. Cotter D, Landau S, Beasley C, Stevenson R, Chana G, MacMillan L, et al. The density and spatial distribution of GABAergic neurons, labelled using calcium binding proteins, in the 
anterior cingulate cortex in major depressive disorder, bipolar disorder, and schizophrenia. Biol Psychiatry 2002;51(5):377-86.

112. Lewis DA. Cortical circuit dysfunction and cognitive deficits in schizophrenia--implications for preemptive interventions. Eur $\mathrm{J}$ Neurosci 2012;35(12):1871-8.

113. Pehrson AL, Sanchez C. Altered gammaaminobutyric acid neurotransmission in major depressive disorder: a critical review of the supporting evidence and the influence of serotonergic antidepressants. Drug Des Devel Ther 2015;9:603-24.

114. Gabbott PL, Bacon SJ. Local circuit neurons in the medial prefrontal cortex (areas 24a,b,c, 25 and 32) in the monkey: II. Quantitative areal and laminar distributions. J Comp Neurol 1996;364(4):609-36.

115. Gilabert-Juan J, Belles $M$, Saez AR, Carceller H, Zamarbide-Fores S, Molto MD, et al. A "double hit" murine model for schizophrenia shows alterations in the structure and neurochemistry of the medial prefrontal cortex and the hippocampus. Neurobiol Dis 2013;59:126-40.

116. Gilabert-Juan J, Castillo-Gomez E, Guirado R, Molto MD, Nacher J. Chronic stress alters inhibitory networks in the medial prefrontal cortex of adult mice. Brain Struct Funct 2013;218(6):1591-605.

117. Guzman-Martinez L, Maccioni RB, Andrade V, Navarrete LP, Pastor MG, RamosEscobar N. Neuroinflammation as a Common Feature of Neurodegenerative Disorders. Front Pharmacol 2019;10:1008.

118. Charlson FJ, Ferrari AJ, Santomauro DF, Diminic S, Stockings E, Scott JG, et al. Global Epidemiology and Burden of Schizophrenia: Findings From the Global Burden of Disease Study 2016. Schizophrenia bulletin 2018;44(6).

119. Yung AR, Firth J. How should physical exercise be used in schizophrenia treatment? Expert Rev Neurother 2017;17(3):213-4 .

120. Terry RD, Gonatas NK, Weiss M. The ultrastructure of the cerebral cortex in Alzheimer's disease. Trans Am Neurol Assoc 1964;89:12.

121. Johnson GV, Hartigan JA. Tau protein in normal and Alzheimer's disease brain: an update. J Alzheimers Dis 1999;1(4-5):329-51.

122. Selkoe DJ. Alzheimer's disease results from the cerebral accumulation and cytotoxicity of amyloid beta-protein. J Alzheimers Dis 2001;3(1):75-80.

123. Querfurth HW, LaFerla FM. Alzheimer's disease. N Engl J Med 2010;362(4):329-44.

124. Du Y, Fu M, Wang YT, Dong $Z$. Neuroprotective Effects of Ginsenoside Rf on Amyloid-beta-Induced Neurotoxicity in vitro and in vivo. J Alzheimers Dis 2018;64(1):309-22.
125. Fung SJ, Webster MJ, Sivagnanasundaram S, Duncan C, Elashoff M, Weickert CS. Expression of interneuron markers in the dorsolateral prefrontal cortex of the developing human and in schizophrenia. Am J Psychiatry 2010;167(12):1479-88.

126. Fung SJ, Fillman SG, Webster MJ, Shannon Weickert C. Schizophrenia and bipolar disorder show both common and distinct changes in cortical interneuron markers. Schizophr Res 2014;155(1-3):26-30.

127. Chance SA, Walker M, Crow TJ. Reduced density of calbindin-immunoreactive interneurons in the planum temporale in schizophrenia. Brain Res 2005;1046(1-2):32-7.

128. Raghanti MA, Spocter MA, Butti C, Hof PR, Sherwood CC. A comparative perspective on minicolumns and inhibitory GABAergic interneurons in the neocortex. Front Neuroanat 2010;4:3.

129. Ferrer I, Tunon T, Serrano MT, Casas R, Alcantara S, Zujar MJ, et al. Calbindin D-28k and parvalbumin immunoreactivity in the frontal cortex in patients with frontal lobe dementia of non-Alzheimer type associated with amyotrophic lateral sclerosis. J Neurol Neurosurg Psychiatry 1993;56(3):257-61.

130. Nishiyama E, Ohwada J, Iwamoto N, Arai $\mathrm{H}$. Selective loss of calbindin D28Kimmunoreactive neurons in the cortical layer II in brains of Alzheimer's disease: a morphometric study. Neurosci Lett 1993;163(2):223-6.

131. Gomez-Tortosa E, Sanders JL, Newell K, Hyman BT. Cortical neurons expressing calcium binding proteins are spared in dementia with Lewy bodies. Acta Neuropathol 2001;101(1):36-42.

132. Pugliese M, Carrasco JL, Geloso MC, Mascort J, Michetti F, Mahy N. Gammaaminobutyric acidergic interneuron vulnerability to aging in canine prefrontal cortex. J Neurosci Res 2004;77(6):913-20.

133. Volk DW, Matsubara T, Li S, Sengupta EJ, Georgiev D, Minabe $Y$, et al. Deficits in transcriptional regulators of cortical parvalbumin neurons in schizophrenia. Am J Psychiatry 2012;169(10):1082-91.

134. Reynolds GP, Beasley CL. GABAergic neuronal subtypes in the human frontal cortex-development and deficits in schizophrenia. J Chem Neuroanat 2001;22(1-2):95-100.

135. Glausier JR, Fish KN, Lewis DA. Altered parvalbumin basket cell inputs in the dorsolateral prefrontal cortex of schizophrenia subjects. Mol Psychiatry 2014;19(1):30-6.

136. Torrey EF, Barci BM, Webster MJ, Bartko JJ, Meador-Woodruff JH, Knable MB. Neurochemical markers for schizophrenia, bipolar disorder, and major depression in 
postmortem brains. Biol Psychiatry 2005;57(3):252-60.

137. Sohal VS, Zhang F, Yizhar O, Deisseroth K. Parvalbumin neurons and gamma rhythms enhance cortical circuit performance. Nature 2009;459(7247):698-702.

138. Acosta C, Anderson HD, Anderson CM. Astrocyte dysfunction in Alzheimer disease. $\mathrm{J}$ Neurosci Res 2017;95(12):2430-47.

139. Vincent AJ, Gasperini R, Foa L, Small DH. Astrocytes in Alzheimer's disease: emerging roles in calcium dysregulation and synaptic plasticity. J Alzheimers Dis 2010;22(3):699-714.

140. Jo S, Yarishkin O, Hwang YJ, Chun YE, Park $M$, Woo $D H$, et al. GABA from reactive astrocytes impairs memory in mouse models of Alzheimer's disease. Nat Med 2014;20(8):88696.

141. Li K, Li J, Zheng J, Qin S. Reactive Astrocytes in Neurodegenerative Diseases. Aging Dis. 2019, p. 664-75.

142. Riviere GR, Riviere KH, Smith KS. Molecular and immunological evidence of oral Treponema in the human brain and their association with Alzheimer's disease. Oral Microbiol Immunol 2002;17(2):113-8.

143. Teixeira FB, Saito MT, Matheus FC, Prediger RD, Yamada ES, Maia CSF, et al. Periodontitis and Alzheimer's Disease: A Possible Comorbidity between Oral Chronic Inflammatory Condition and Neuroinflammation. Front Aging Neurosci 2017;9:327.

144. Li T, Chen X, Zhang C, Zhang Y, Yao W. An update on reactive astrocytes in chronic pain. J Neuroinflammation. 2019.

145. Ciesielska A, Joniec I, KurkowskaJastrzebska I, Cudna A, Przybylkowski A, Czlonkowska $A$, et al. The impact of age and gender on the striatal astrocytes activation in murine model of Parkinson's disease. Inflamm Res 2009;58(11):747-53.

146. Hirsch EC, Hunot S. Neuroinflammation in Parkinson's disease: a target for neuroprotection? Lancet Neurol 2009;8(4):38297.

147. Lee HJ, Suk JE, Patrick C, Bae EJ, Cho $\mathrm{JH}$, Rho $\mathrm{S}$, et al. Direct transfer of alphasynuclein from neuron to astroglia causes inflammatory responses in synucleinopathies. J Biol Chem 2010;285(12):9262-72.

148. Gu XL, Long CX, Sun L, Xie C, Lin X, Cai $\mathrm{H}$. Astrocytic expression of Parkinson's disease-related A53T alpha-synuclein causes neurodegeneration in mice. Mol Brain 2010;3:12.

149. Halliday GM, Stevens CH. Glia: initiators and progressors of pathology in Parkinson's disease. Mov Disord 2011;26(1):6-17.

150. Barcia C, Ros CM, Annese V, Gomez A, Ros-Bernal F, Aguado-Llera D, et al. IFNgamma signaling, with the synergistic contribution of TNF-alpha, mediates cell specific microglial and astroglial activation in experimental models of Parkinson's disease. Cell Death Dis 2012;3:e379.

151. Sofroniew MV. Astrogliosis. Cold Spring Harb Perspect Biol 2014;7(2):a020420.

152. Liberman AC, Trias E, da Silva Chagas $L$, Trindade P, Dos Santos Pereira M, Refojo D, et al. Neuroimmune and Inflammatory Signals in Complex Disorders of the Central Nervous System. Neuroimmunomodulation 2018;25(56):246-70.

153. Carroll JA, Chesebro B. Neuroinflammation, Microglia, and CellAssociation during Prion Disease. Viruses. 2019.

154. Kaur D, Sharma V, Deshmukh R. Activation of microglia and astrocytes: a roadway to neuroinflammation and Alzheimer's disease. Inflammopharmacology 2019;27(4):663-77.

CONFLICTS OF INTERESTS

The authors declare no conflicts of interests.

CORRESPONDING AUTHOR

\section{Gestter Willian Lattari Tessarin}

University Center North Paulista, UNORP Ipiranga Street, 3460 - Jardim Alto Rio Preto 15020-040 São José do Rio Preto - SP, Brazil E-mail: gestter@unorp.br 